\title{
The Impact of Productive Zakat on the Income Inequality of Mustahiq in Yogyakarta
}

\author{
Susilo Nur Aji Cokro Darsono ${ }^{1}$, Mitha Raihana ${ }^{1}$, Hafsah Fajar Jati ${ }^{1}$, \\ dan Anisya Pachmi ${ }^{1}$
}

\begin{abstract}
Inequality in income distribution is one of the economy problems that faced by most developing countries, including Indonesia. In order to reduce the income gap, Islam proposes instruments to solve this problem, such as Zakat. This is not only an obligation for the Muslim but it also has the goal of improving the economy conditions in society. There is the movement of wealth from high income society to low income society in zakat, so the income will not be concentrated in a certain society. Zakat distribution can support the achievement one of the Sustainable Development Goals (SDGs), namely goal 10, which is to reduce inequalities. This research aims to analyze the effect of productive zakat on reducing income inequality among mustahiq or zakat recipients. A survey employing a questionnaire was applied in this research to find the data from mustahiq population in Yogyakarta City. Lorenz curve, Gini ratio index and World Bank inequality criteria were applied to analyze the inequality of income distribution. This research found that distribution of productive zakat decreased the inequality of income among mustahiq as shown by the decreasing area in the Lorenz curve. In addition, the Gini ratio also fell from 0.37 to 0.30 which shows the decrease in income inequality among mustahiq. Finally, the proportion of income in $40 \%$ low income society increased from $16.83 \%$ to $21.04 \%$.
\end{abstract}

Keywords: Income Inequality; Productive Zakat; Mustahiq.

\section{Introduction}

Indonesia is one of the developing countries that face the problem of income inequality. Income inequality at a certain level can be positive, because it provides opportunities for those who want to work hard and innovate to obtain rewards. However, high-income inequality can be a negative effect on economic growth, slow down poverty alleviation, and weaken social harmony (Sastra, 2017).

In Indonesia, the level of inequality indicated by the Gini ratio has increased in the last ten years. According to data from Indonesian Bureau of Statistics (BPS) from 2006-2008, this level fluctuated from 0.33 to 0.36 . Inequality rates slowly rose between 2009 and 2015 from 0.36 to 0.41 , although the Gini ratio fell in 2016-2017 to 0.39. Every province in Indonesia has an inequality problem. According to BPS data from 2017, five provinces had the highest inequality, as reflected in the Gini index. In first position was the Special Region of Yogyakarta (DIY), with a Gini Index of 0.44. Second was the Province of South Sulawesi, with a Gini index of 0.42 , followed by East Java Province with an index of 0.41 . The fourth and fifth highest Gini index scores were in Gorontalo and Southeast Sulawesi provinces, both at 0.40 . From these data, it can be seen that DIY was the 
province with the highest inequality in Indonesia. It is divided into five regions: one city, namely Yogyakarta City, and four regencies, Sleman Regency, Bantul Regency, Gunung Kidul Regency, and Kulon Progo Regency. Each of these regions had a different Gini Index.

Table 1 shows that for the past seven years, apart from 2015, the city of Yogyakarta had the highest Gini index in Yogyakarta Province. Almost every year, income inequality in the city increased. It falls into the criteria for moderate levels of inequality, which demonstrates that the results of the development by the Yogyakarta City government have not been felt by all the population evenly. This increased income inequality must be overcome, as it is can cause social jealousy and worsening poverty. According to the research by Darsono and Donkwa (2016), poverty is identified by income level.

Table 1 Gini Index in the Special Region of Yogyakarta

\begin{tabular}{lllllllll|}
\hline City/Regency & Year & & & & & & & \\
& 2010 & 2011 & 2012 & 2013 & 2014 & 2015 & 2016 & $\mathbf{2 0 1 7}$ \\
\hline Yogyakarta & 0,37 & 0,35 & 0,36 & 0,44 & 0,42 & 0,44 & 0,43 & $\mathbf{0 , 4 5}$ \\
Sleman & 0,37 & 0,42 & 0,47 & 0,39 & 0,41 & 0,45 & 0,40 & $\mathbf{0 , 4 1}$ \\
Bantul & 0,32 & 0,38 & 0,41 & 0,33 & 0,32 & 0,38 & 0,40 & $\mathbf{0 , 4 1}$ \\
Kulon Progo & 0,27 & 0,39 & 0,42 & 0,31 & 0,38 & 0,37 & 0,37 & $\mathbf{0 , 3 9}$ \\
Gunung Kidul & 0,27 & 0,34 & 0,37 & 0,27 & 0,30 & 0,32 & 0,33 & $\mathbf{0 , 3 4}$ \\
\hline
\end{tabular}

Source: Susenas BPS, 2018

It showed that there are 2 of the factors that are positively related to people's income in Senujuh Village, West Borneo, namely the number of working days and the number of loans according to people's ability to pay them back. People need to increase their number of working days to increase their average income, and will use loans as capital to develop their businesses and help to increase their income. Most of villagers obtain loans from debt collectors, family, and through leasing. There is no cooperative in Senujuh village or nearby.

Islam has various instruments to increase income, and consequently reduce income inequality, one of which is zakat. This is an obligation for all Muslims who fulfill the requirements to make donations of at least 2.5 percent of their accumulated wealth or income, which is given to the poor and other recipients of zakat called mustahiq (in accordance with the eight asnaf). Zakat aims to provide services and benefits and to improve the welfare of the mustahiq. The word zakat is mentioned as many as 59 times in the Qur'an, 27 in one verse with the command of prayer. It indicates that good Muslims are those who always balance individual and social worship (Andiani, 2018). Islam does not only regulate human relations with Allah (habluminallah) but also the relationships between humans (habluminanas), which must be maintained correctly and in a balanced way. In this way, it is intended that humans can achieve happiness living in the world and the hereafter (Amar, 2017). Zakat is one form of Islamic teaching on sharing and caring. It can strengthen the brotherhood relationship of Muslims and is a means for individuals or muzaki to purify their wealth and the hearts of believers of unwanted desires such as greed, self-indulgence, hedonism and decadence, whilst the 
recipient is purified of envy because of the many assets owned by rich people. As the third pillar of Islam, the function of zakat is not only from a religious perspective, but also from an economic development viewpoint. In zakat there is a transfer of part of the wealth of people who have sufficient or excess assets to people in need, so that assets will not accumulate within a certain group of people. Therefore, it can minimize the inequality of income distribution.

Zakat is an effective instrument in overcoming the problem of poverty and income inequality. Its significance in terms of poverty alleviation and income inequality reduction is reflected in Al Quran, including Quran Surah At-Taubah verse 60 and Quran Surah Al Hasyr verse 7 (Ayyuniah, 2018). At the time of the Prophet Muhammad (Rasulullah), ukhuwwah Islamiyah was greatly emphasized. Rasulullah was very aware that the principle of togetherness, kinship and brotherhood was a program that could boost people's economic growth and alleviate the poverty that afflicted Muslims. It was obtained from the values of the Qur'an of respecting fellow human beings and emphasizing ukhuwah/brotherhood (Surah al-Hujarat: 10) and ta'awun/help/togetherness (Qs. Al-Maidah: 3). The importance of zakat, infaq, and sadaqah, abbreviated to ZIS, has been outlined in the teachings of Islam. The government can rule the community to pay zakat to the Board of Zakat or Amil, which has been established in all provinces, districts and sub-districts. The Board of Zakat or Amil will then manage and distribute the zakat to the needy or poor. This helps them to obtain their basic needs and improve their standard of living in order to have a decent life. ZIS is a means of reducing the gap between the rich and the poor (Fathurrahman, 2012).

The National Board of Zakat (BAZNAS) in Yogyakarta is an Amil zakat, established by the government in the city. The BAZNAS of Yogyakarta can receive payment of zakat, infaq and sadaqah for distribution to whoever is in need, in accordance with the eight asnaf. The zakat and infaq funds obtained by BAZNAS in Yogyakarta are managed and distributed in the form of consumptive and productive zakat. Consumptive zakat is more conditional, such as scholarships, and social funds for sick people and victims of natural disasters. On the other hand, productive zakat is business capital assistance, which can produce profits while increasing mustahiq income, so that the benefits can be received in the long run. According to this concept, zakat can be a means of sustainable development. Moreover, its distribution has been innovated in the form of business capital or productive zakat.

Zakat funds have great potential for increasing mustahiq income. With good management, they will be able to increase mustahiq productivity. (Ikram, 2016). In this regard, the institution of zakat is considered as one of the most effective mechanisms for dealing with the dual problems of poverty and income inequality (Ayyuniah, 2018). Therefore, this research aims to ascertain how zakat can reduce the income inequality of mustahiq in the case study of the BAZNAS in Yogyakarta. 
Darsono, Raihana, Jati, \& Pachmi

The Impact of Productive Zakat on the Income Inequality ...

\section{Literature Review}

The development requires higher GNI and sustained growth. The basic issue is not only how to make GNI grow but also who will do this. If the rich, it would be profitable mostly to them, progress on reducing poverty would be slow, and inequality would worsen. But if it is generated by the many, they would all be beneficiaries, and the outcome of economic growth would be shared more evenly. Income inequality is the disproportionate distribution of total national income among households. For both analytical and quantitative purposes, economists usually distinguish between two principal measures of income distribution: the size distribution of income and production factor income. The distribution of income relates to the size of the class of persons; for example, the proportion of total income from a certain percentage which is obtained from the poorest or the richest, without regard to the sources of that income. Another common way to analyze personal income statistics is to construct what is known as a Lorenz curve. This is a graph depicting the variance in size distribution of income from perfect equality. A final and very convenient shorthand summary measure of the relative degree of income inequality in a country can also be obtained by calculating the Gini coefficient. This is an aggregate numerical measure of income inequality, ranging from 0 (perfect equality) to 1 (perfect inequality). The second common measure of income distribution used by economists, the factor share distribution of income, attempts to explain the share of total national income that each of the factors of production (land, labor and capital) receives (Todaro \& Smith, 2011). According to Sastra (2017), there are several factors that cause inequality: (i) failures in public institutions and policies; (ii) poverty and lack of investment in basic infrastructure; (iii) provision of employment and economic structures; (iv) rent-seeking; (v) market failure; (vi) globalization : political and democratic factors; and (vii) historical factors.

Beik and Arsyanti (2016) argue that Islam sees differences and inequality as natural. They occur because people are born into different backgrounds. This is stated in the Quran Al-An'am: 165. Differences and inequality are one form of test for both highincome and low-income groups. Because of them, it has become the duty of humans as khalifah on earth to manage them so that existing differences and inequality can create harmony and can complement each other according to people's respective abilities and roles.

The human role has been outlined by Allah SWT in Al Quran Az-Zukhruf verse 32. In this surah, Allah has given advantages to some of His servants to be used for good. An entrepreneur or capital owner is unlikely to operate his company without employees, who are needed according to their expertise. The manager of a cleaning service certainly has a different position, so the salary received will be different. This difference is not a form of discrimination, because Islam has placed everything according to its place and portion. People who have excess will have greater responsibilities. If they have more wealth, it is their responsibility to care for those who lack it. Such care can be in the form of giving zakat, infaq, wakaf or hibah in the form of money, goods or business 
capital. In other words, there will be a transfer of the ownership of assets, so that any inequality due to differences in background or ability can be reduced.

Zakat comes from the word al barakatu, which means blessing; al namaa', which means growth; ath-thaharu, which means holiness, and ash-shalahu, which means success or good. It relates to wealth which God asks the owner to give to those who have the right to receive it, with certain conditions. The definition of zakat literally and termonologically has a close relationship, namely that the wealth issued by zakat will be a blessing, increased, holy, and good. This is stated in the Al Qur'an Surah At-Taubah verse 103 (Hafidhuddin, 2004):

"Receive contributions from their wealth, to purify them and sanctify them with it; and pray for them. Your prayer is a comfort for them. God is Hearing and Knowing." (Al - Qur'an Surah At-Taubah:103)

The types of zakat recipient, as abstracted from Al-Quran surah At-Taubah: 60 (Rozalinda, 2014) are:

1. Fakir, an individual Muslim who does not have a job and does not have enough for his/her daily needs.

2. Poor, an individual Muslim who has a job but does not have enough for his/her daily needs.

3. Amil, people who are directly involved in the management and administration of zakat affairs.

4. Mu'allaf, those who are new to Islam and need help to adjust to their new circumstances.

5. Riqab, a slave who wants to free himself.

6. Gharimin, those who are in debt because of their lawful needs and are unable to meet their payments.

7. Fisabilillah, those who are struggling in the way of Allah, for example da'wah war.

8. Ibnu Sabil, the wayfarer who ran out of money on his trip.

The command of zakat began in the second year of the hijriyah, when the Prophet Muhammad migrated from Mecca to Medina (Amar, 2017). Zakat has positive impacts related to the spiritual, economic and social dimensions. It is an expression of gratitude to God for the sustenance that has been given, and from a moral perspective, it has a positive impact on muzaki and mustahiq. For muzaki, zakat will cleanse and purify the soul from stinginess and greed. In a hadith, the prophet Muhammad explained "Everyone who gets a pleasure will be the target of envious and jealous of others" (HR. ath-Thabrani) and "The attitude of the heart is inclined to love those who do good to him and hate those who do bad to him" (HR. Al-Baihaqi). Therefore, zakat cleanses and purifies the soul of mustahiq from envy (Alfaizin, 2018). In addition, zakat teaches the lesson that people must care for and show affection to each other. From a social perspective, zakat can eliminate the gap between the rich and the poor, while from the economic perspective it exemplifies correct business ethics, and prevents the accumulation of wealth by a few people with a high income. Zakat is able to reduce 
unemployment, because of the jobs created to manage zakat, infaq and sadaqah funds. In addition, the source of zakat funds can be distributed as capital for the poor, so that they have jobs and income and are able to fulfill their basic needs. Therefore, zakat is able to reduce poverty, create equitable income, and improve the welfare of mustahiq (Rozalinda, 2014).

One of the successes of zakat occurred in the Khalifah Umar bin Abdul Aziz era. Umar bin Abdul Aziz followed the sunah of the Prophet Muhammad SAW in terms of zakat withdrawal. He pointed officers who were trustworthy and instructed them who had more assets or wealth to collect these assets obliged to be paid as zakat. He then instructed the officers to note the receipts for the payers of zakat. Umar bin Abdul Aziz ensured that every group who met the criteria of zakat recipients must receive zakat in their regions unless they had sufficient income. Umar bin Abdul Aziz encouraged people to pay zakat because it was a direct command from Allah SWT in Quranic verse, Al Baqarah: 110 (Kuliman, 2016).

"And perform the prayer, and give alms. Whatever good you forward for yourselves; you will find it with God. God is Seeing of everything you do." (Al Quran Al Baqarah:110)

Moreover, zakat has an impact on another people's welfare. Basically, it can also be interpreted as income redistribution, through which people who have excess assets share these with disadvantaged Muslims. Ayyuniah (2018) researched zakat distribution programs in poverty alleviation and income inequality reduction among groups in urban and rural areas of West Java, Indonesia. The analytical tools used were modified from the Centre of Islamic Business and Economic Studies (CIBEST) model, the deciles method and the Gini coefficient. The research showed that zakat distribution programs can alleviate poverty and reduce income inequality among the observed zakat beneficiaries.

Other research was conducted by Rarasati (2017) on the potential Agricultural Zakat of Pineapple to reduce inequality of income distribution and to alleviate poverty in Beluk Village, Pemalang Regency. Rarasati employed the FGT index, the specifically headcount ratio, the poverty gap index, and poverty severity index as the tools for measuring poverty, and the Lorenz curve, Gini index, and World Bank criteria as the tools for analyzing income inequality. The results show that the level of poverty in terms of proportion, depth and severity fell. The potential Agricultural Zakat of Pineapple did not only reduce poverty, but also reduced income inequality, as indicated by the decrease in the area of the Lorenz curve. The Gini ratio was also reduced from 0.51 to 0.45 and the proportion of income in $40 \%$ low-income society increased from $12.46 \%$ to $15.92 \%$.

Research by Tsani (2010) showed that the distribution of zakat by BAZDA in South Lampung could reduce the number of poor families, the level of poverty and its severity. This could be seen from the incidence of poverty (the number of poor families), which decreased by 18.6 percent after the distribution of zakat was implemented. In addition, in terms of the depth of poverty, the poverty gap index (P1) decreased from 
Rp205,632.25 to Rp166,421.78, and the poverty severity index(I) decreased from 0.288 to 0.233. Zakat distribution was able to improve income distribution among poor families, as characterized by a decrease in the Sen Index value from 0.194 to 0.131 and in the FGT Index, which fell from 0.054 to 0.030 . Distribution of zakat not only reduced the level of poverty, but also reduced income inequality. The Gini index fell from 0.638 to 0.625 and the Kuznets ratio also fell from 16.7 to 14.4 .

\section{Research Method}

The data for the study is primary data obtained through questionnaires, with a total of 71 respondents, who were productive zakat assistance beneficiaries managed by the National Board of Zakat (BAZNAS) in Yogyakarta. Data collection was conducted between July and August 2018, or for about a month.

Instruments that are often used as tools to measure income inequality are the Lorenz curve and Gini index (Beik \& Arsyanti, 2016). Similarly, according to Todaro (2011), for both analytical and quantitative purposes economists usually distinguish between two principal measures of income distribution: the size distribution of income and the production factor. The tools usually employed to establish income inequality is through measurement using the Lorenz curve and Gini index. For that reason, we employed both these as measurement tools for measuring the level of income inequality. Morover, additional calculations were made based on the World Bank criteria to ascertian what percentage of income was enjoyed by $40 \%$ of low income society.

The Lorenz curve is located on a square, which connects population groups (horizontal axis) and income groups (vertical axis), to find the proportion of income that can be enjoyed by certain population groups. The farther the curve is located from the equalization line, the higher the inequality of income distribution in the region, and vice versa (Todaro \& Smith, 2011).

The Gini ratio calculation is derived from the measurement of the Lorenz curve. The area of the Lorenz curve can be obtained by calculating the ratio of the fields between the diagonal area and the Lorenz curve, then divided by the total half-square area where the curve is located, as can be seen in Figure 1. 


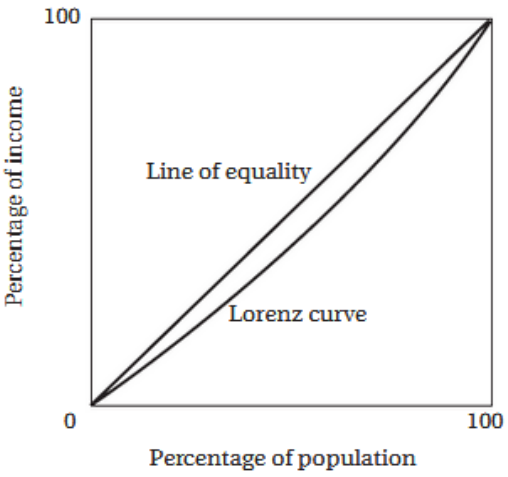

(a) A relatively equal distribution

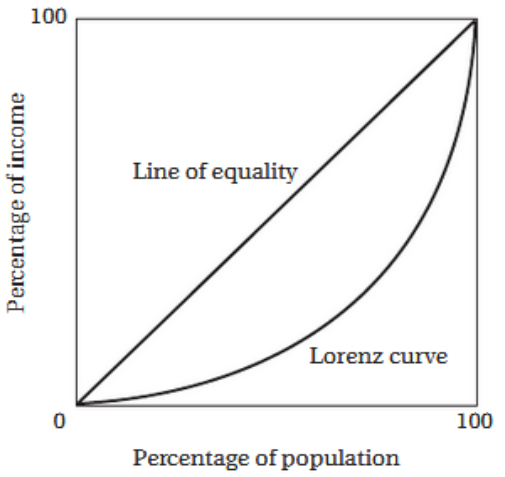

(b) A relatively unequal distribution

Figure 1 Lorenz curve

Source: Todaro and Smith (2011)

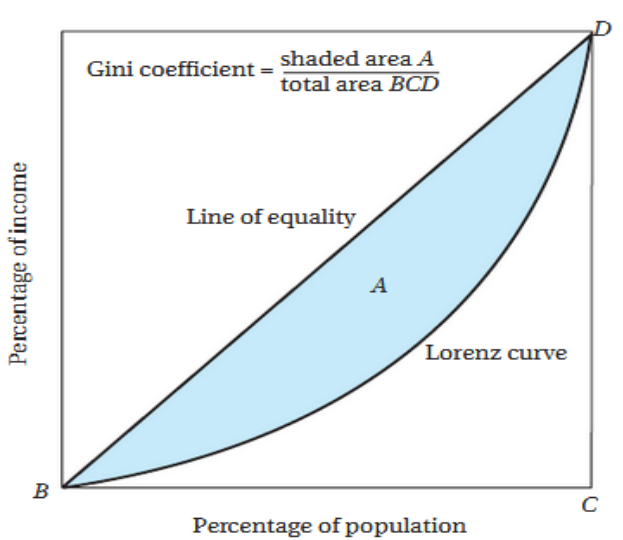

Figure 2 Calculation of the Area of the Lorenz curve for the Gini Index

Source: Todaro and Smith (2011)

The value of the Gini ratio index ranges from 0 to 1 ; the closer to 1 , the greater the inequality. The Gini ratio is divided into three groups, namely low, moderate and high. A Gini ratio of $<0.3$ is categorized as low inequality, one of $0.3-0.5$ is categorized as moderate inequality, and one greater than 0.5 is categorized as high inequality (BPS, 2014).

According to World Bank criteria, the level of income inequality can be determined by measuring what proportion of income is enjoyed by $40 \%$ of the low-income population. The World Bank stipulates three criteria for population income distribution: $40 \%$ of the low-income population; $40 \%$ of the middle-income population; and $20 \%$ of the highincome population. If $40 \%$ of the low-income population has less than $12 \%$ of the total income, it is categorized as high-income inequality; between $12 \%$ and $17 \%$ it is categorized as moderate-income inequality; and more than $17 \%$ it is categorized as lowincome inequality (BPS, 2014). 


\section{Results and Discussion}

The city of Yogyakarta is the capital of Daerah Istimewa Yogyakarta (DIY) Province, with a total area of $32.5 \mathrm{~km}^{2}$, or $1.02 \%$ of the area of DIY Province. Administratively, it is named Yogyakarta. The municipality comprises 14 sub-districts, 45 urban villages, 616 hamlets and 2,532 neighborhoods, with boundaries to the north of Sleman Regency; to the east Bantul and Sleman Regency; to the south Bantul Regency; and to the west Bantul and Sleman Regency. The total population of Yogyakarta Municipality in 2017, based on the population projection of BPS-Statistic Indonesia, was 422,732 male and 216,311 females (BPS, Kota Yogyakarta dalam Angka, 2018).

Table 2 Respondent Characteristics

\begin{tabular}{lcc}
\hline Characteristic & Total & Percentage \\
\hline Sex & 31 & $\mathbf{4 3 . 7 \%}$ \\
Male & 40 & $\mathbf{5 6 . 3 \%}$ \\
Female & & \\
Age Group & 7 & $\mathbf{9 . 8 \%}$ \\
\hline$<\mathbf{2 5}$ years & 9 & $\mathbf{1 2 . 6 \%}$ \\
$\mathbf{2 6 - 3 5}$ years & 23 & $\mathbf{3 2 . 3 \%}$ \\
$\mathbf{3 6 - 4 5}$ years & 25 & $\mathbf{3 5 . 2 \%}$ \\
$\mathbf{4 6 - 5 5}$ years & 7 & $\mathbf{9 . 8 \%}$ \\
$>$ 56 years & & \\
Status & 9 & $\mathbf{1 2 . 7 \%}$ \\
Single & 52 & $\mathbf{7 3 . 2 \%}$ \\
Married & 14 & $\mathbf{1 4 \%}$ \\
Divorced & & $\mathbf{1 2 . 6 \%}$ \\
Formal Education & 9 & $\mathbf{1 4 \%}$ \\
Elementary School & 10 & $\mathbf{7 0 . 4 \%}$ \\
Junior High School & 50 & $\mathbf{2 . 8 \%}$ \\
Senior High School & 2 & $\mathbf{3 0 . 9 \%}$ \\
Other & & $\mathbf{1 1 . 2 \%}$ \\
Occupation & 22 & $\mathbf{2 9 . 6 \%}$ \\
\hline Housewife & 8 & $\mathbf{1 2 . 7 \%}$ \\
Laborer & 21 & $\mathbf{1 5 . 4 \%}$ \\
Entrepreneur & 9 & \\
Employee & 11 & \\
Other & & \\
\hline
\end{tabular}

Yogyakarta City has a zakat board called The National Board of Zakat (BAZNAZ) of Yogyakarta City, which has the main tasks of collecting, managing, distributing and being accountable for zakat, infaq and sadaqah funds, in accordance with sharia provisions and applicable regulations. BAZNAS Yogyakarta runs several programs, namely Jogja Taqwa, Jogja Sehat, Jogja Cerdas, Jogja Peduli, and Jogja Sejahtera. Jogja Taqwa is a program directed at increasing the understanding and practice of Islam, improving the infrastructure of places of prayer and madrasa, and providing scholarships for students who have made achievements in religion. Jogja Cerdas is a program to improve the quality of underprivileged students, such as scholarship programs and BAZNAS smart 
homes. Jogja Sehat is a program to relieve the medical costs of mustahiq, while Jogja Peduli aims to ease the situation of people affected by natural disasters. Finally, Jogja Sejahtera deals with the distribution of productive zakat to improve the situation of economically disadvantaged people, especially orphans, poor people, the disabled, clerics, mosque guards, and converts to Islam (muallaf). It also provides a program of business capital assistance, both in the form of goods capital and money capital. In addition, mustahiq are given lessons about how to manage businesses and on spiritual development to improve understanding and practice of Islam.

In this research, the respondents were zakat productive recipients, comprising 70 mustahiq, 31 male and 40 females. The characteristics of the respondents were based on sex, age, education, occupation and marital status. Based on the data, the largest age group was 46 - 55 years old, the most common occupation was housewife, with a percentage of $30.9 \%$, and followed by entrepreneurs at $29.6 \%$.

Figure 3 shows two Lorenz curves, which are limited by the 45 -degree blue line. The red curve represents the situation before the distribution of zakat; in other words, the mustahiq have not received productive zakat assistance.

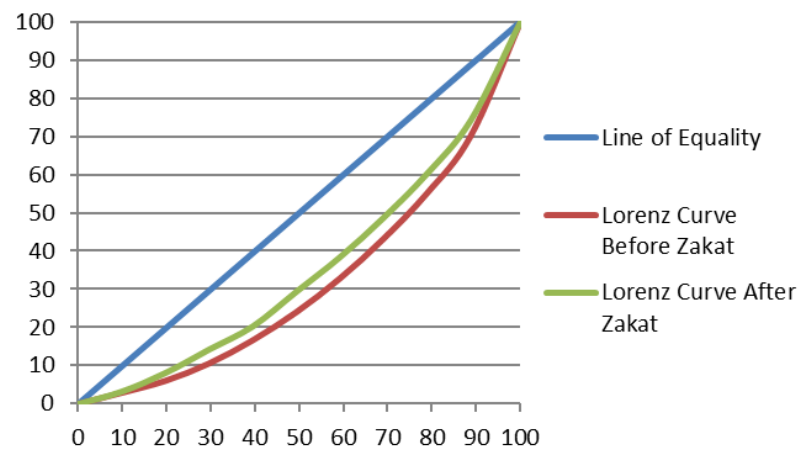

Source: Results of Microsoft Excel data processing

Figure 3 Lorenz Curve Before and After Productive Zakat Distribution by BAZNAS Yogyakarta

The green Lorenz curve corresponds to the situation after the distribution of zakat; in other words, the mustahiq have received productive zakat assistance. This curve shows that zakat is able to reduce gaps in income distribution, as indicated by the closer distance of the green Lorenz curve to the line of equality.

Based on the calculations from the Lorenz curve, changes are seen in the level of income inequality before and after the distribution of zakat. The Gini coefficient falls from 0.37 to 0.30 .

In the calculation method according to the World Bank criteria, the income inequality between mustahiq belonged to the moderate category, as $40 \%$ of the low-income residents received or enjoyed $16.83 \%$ of the total income. After the distribution of 
productive zakat by BAZNAS in the City of Yogyakarta, $40 \%$ of the low-income population received $21.04 \%$ of the total income, so the level of inequality was now classified as low.

This research aims to ascertain the role of productive zakat distribution in income inequality reduction among mustahiq in Yogyakarta using the Lorenz curve calculation, the Gini index, and calculation according to the criteria of the World Bank. In the study, the respondents are productive zakat recipients, comprising 71 mustahiq, 31 male and 40 females. From Tables 3 and 4, it can be seen that income inequality has been reduced with the help of productive zakat distribution.

Tabel 3 Calculation Gini Index Before Zakat

\begin{tabular}{|c|c|c|c|c|c|c|c|}
\hline Income & $\begin{array}{l}\% \\
\text { Population }\end{array}$ & $\begin{array}{l}\% \\
\text { Income }\end{array}$ & $\begin{array}{l}\text { Cumulative \% } \\
\text { Income (Yi) }\end{array}$ & $(Y i+Y i-1) / 100$ & $\begin{array}{l}\text { Area } \\
\text { under } \\
\text { the } \\
\text { Lorenz }\end{array}$ & Area A & $\begin{array}{l}\text { Gini } \\
\text { Coefficient }\end{array}$ \\
\hline $3,500,000$ & 10 & 3.022 & 3.022 & 0.030 & 0.003 & \multirow[t]{11}{*}{0.184} & \multirow[t]{11}{*}{0.37} \\
\hline $3,700,000$ & 10 & 3.195 & 6.218 & 0.092 & 0.009 & & \\
\hline $5,300,000$ & 10 & 4.577 & 10.794 & 0.170 & 0.017 & & \\
\hline $7,000,000$ & 10 & 6.045 & 16.839 & 0.276 & 0.028 & & \\
\hline $8,600,000$ & 10 & 7.427 & 24.266 & 0.411 & 0.041 & & \\
\hline $10,200,000$ & 10 & 8.808 & 33.074 & 0.573 & 0.057 & & \\
\hline $11,900,000$ & 10 & 10.276 & 43.351 & 0.764 & 0.076 & & \\
\hline $14,750,000$ & 10 & 12.737 & 56.088 & 0.994 & 0.099 & & \\
\hline $18,450,000$ & 10 & 15.933 & 72.021 & 1.281 & 0.128 & & \\
\hline $32,400,000$ & 10 & 27.979 & 100 & 1.720 & 0.172 & & \\
\hline $115,800,000$ & 100 & & & & 0.316 & & \\
\hline
\end{tabular}

Source: Results of Microsoft Excel data processing

Tabel 4 Calculation Gini Index After Zakat

\begin{tabular}{|c|c|c|c|c|c|c|c|}
\hline Income & $\begin{array}{l}\% \\
\text { Population }\end{array}$ & $\%$ Income & $\begin{array}{l}\text { Cumulative \% } \\
\text { Income (Yi) }\end{array}$ & $\begin{array}{l}(Y i+Y i- \\
1) / 100\end{array}$ & $\begin{array}{l}\text { Area } \\
\text { under the } \\
\text { Lorenz }\end{array}$ & Area A & $\begin{array}{l}\text { Gini } \\
\text { Coefficient }\end{array}$ \\
\hline $5,000,000$ & 10 & 3.233 & 3.233 & 0.032 & 0.003 & 0.151 & 0.3 \\
\hline $7,250,000$ & 10 & 4.688 & 7.921 & 0.112 & 0.011 & - & - \\
\hline $9,300,000$ & 10 & 6.014 & 13.935 & 0.219 & 0.022 & - & - \\
\hline $11,000,000$ & 10 & 7.113 & 21.048 & 0.350 & 0.035 & - & - \\
\hline $12,400,000$ & 10 & 8.018 & 29.066 & 0.501 & 0.050 & - & - \\
\hline $14,000,000$ & 10 & 9.053 & 38.118 & 0.672 & 0.067 & - & - \\
\hline $17,200,000$ & 10 & 11.122 & 49.240 & 0.874 & 0.087 & - & - \\
\hline $18,550,000$ & 10 & 11.995 & 61.235 & 1.105 & 0.110 & - & - \\
\hline $21,950,000$ & 10 & 14.193 & 75.428 & 1.367 & 0.137 & - & - \\
\hline $38,000,000$ & 10 & 24.572 & 100.000 & 1.754 & 0.175 & - & - \\
\hline $154,650,000$ & 100 & - & - & - & 0.349 & - & - \\
\hline
\end{tabular}

Source: Results of Microsoft Excel data processing

From the calculations in Table 3 and Table 4, it can be seen in the area A from Figure 3, which is the area between line of equality and Lorenz curve, are used to calculate the Gini coefficient. After the distribution of productive zakat, the area under the Lorenz curve is wider from 0.316 to 0.349 (the highlighted cells), hence as a result the area $A$ 
will be narrowing from 0.186 to 0.15 only. Figure 3 has depicted how much this change because the Lorenz curve after distribution of productive zakat (the green curve) is closer to the equalization line rather than before distribution of productive zakat (the red curve).

The measurement results using the Lorenz curve show that its area after the distribution of zakat narrows compared to before the distribution; in other words, after the distribution of zakat the Lorenz curve moves closer to the equalization line. After one year of productive zakat distribution, income inequality based on the calculation results using the Gini ratio index fell from 0.37 to 0.30 .

Tabel 5 Results of Calculation by Gini Index

\begin{tabular}{lll}
\hline Formula & Before Zakat & After Zakat \\
& $G_{1}=\frac{\text { ShadedArea } A}{\text { TotalAreaBCD }}$ & $G_{2}=\frac{\text { ShadedAreaA }}{\text { TotalAreaBCD }}$ \\
Lorenz curve Area & 0.184 & 0.15 \\
Gini Index & 0.37 & 0.30 \\
\hline
\end{tabular}

Source: Results of Microsoft Excel data processing

Table 6 Calculation according to the criteria of the world bank

\begin{tabular}{lllll|}
\hline Group & $\begin{array}{l}\text { Percentage of Income } \\
\text { Before Zakat }\end{array}$ & After Zakat & Before Zakat & After Zakat \\
\hline $\begin{array}{l}\text { 40\% low-income } \\
\text { society }\end{array}$ & $16.83 \%$ & $21.04 \%$ & Rp 19,550,000.00 & Rp 32,550,000.00 \\
$\begin{array}{l}\text { 40\% middle-income } \\
\text { society }\end{array}$ & $39.24 \%$ & $40.18 \%$ & Rp 45,450,000.00 & Rp 62,150,000.00 \\
$\begin{array}{l}\text { 20\% high-income } \\
\text { society }\end{array}$ & $43.91 \%$ & $38.76 \%$ & Rp 50,850,000.00 & Rp 59,950,000.00 \\
Total & $100 \%$ & $100 \%$ & Rp 115,550,000,00 & Rp156,075,000,00 \\
\hline
\end{tabular}

Source: Results of Microsoft Excel data processing

From the calculations according to the World Bank criteria, the proportion of income received by $40 \%$ of low-income society increased from $16.83 \%$ to $21.04 \%$. If imagined as the distribution of 100 pieces of cake, then 40 people get 13 pieces of cake, 40 middle income people get 40 slices of cake and 20 people with the highest income get 47 pieces of cake (BPS, Gini Ratio Kota Yogyakarta 2016, 2017). Based on these criteria, the income distribution of recipients of productive zakat by BAZNAS Yogyakarta is included in the category of moderate inequality, because $40 \%$ of low-income residents receive or enjoy $16.83 \%$ of the total income. After the distribution of productive zakat by BAZNAS, $40 \%$ of the low-income population received $21.04 \%$ of total income, so the level of inequality was now classified as low.

Some previous studies found the similar results as what has been found in this research that zakat can reduce the income inequality. One was conducted by Johari, Aziz, and Ali (2014) on the role of zakat in between converts (muallaf) in Selangor, Malaysia. They used the Lorenz curve and the Gini ratio index to measure the level of income inequality. In the research, two kinds of Lorenz curve are in fact employed, one before zakat and 
one after. That after zakat is closer to the equalization line than the one before zakat. In addition, the Gini ratio fell from 0.58 to 0.53 . Other research by Tsani (2010) obtained the result that zakat could reduce income inequality in two sub-districts in Lampung Province. This was shown by the decreasing area of the Lorenz curve and a fall in Gini ratio from 0.638 to 0.625 . The Kuznets ratio also decreased from 16.7 to 14.4 . Similarly, three types of calculations employed in this research has resulted the same thing that putting the distribution of productive zakat into the economy would be beneficial to reduce income inequality. Both Lorenz curve and Gini coefficient are better as well as the calculation of World Bank criteria resulting the total income is higher for all levelincome societies.

Ayief Fathurrahman (2012) has written his concern about fiscal policy in Indonesia on alleviating the problem of poverty in the perspective of Islamic economics. In his study, poverty is not only related to cultural problems, but also structural ones. A country makes fiscal policy-oriented to reduce poverty. Culturally, Islam has recommended the role of the individual in improving the quality of life through zakat, infaq, and sadaqah. Structurally, Islam has laid down the central role of the state in creating the distribution of income and wealth in a fair and equitable way, and maintaining the stability and sustainability of economic development.

Zakat distribution is in line with the implementation of sustainable development goals (SDGs) number 10, that is to "reduce inequalities". There are some traits which differentiate zakat from SGDs, the main one being that zakat is basically rooted in Islamic teachings, while SDGs are neither a religious product nor linked directly with a specific religion. However, there are some clear similarities between SDGs and zakat. Many of the features of SDGs do not contradict the reflection of Islamic values. Among the 17 SDGs, some concern reducing poverty and hunger, as well as reducing inequality by the distribution of wealth. These goals are obviously in line with the principles of zakat in Islam. In Islamic beliefs, there are five fundamental goals, known as Maqasid alSharia: the protection of faith (hifdh-ul-iman); life (hifdh-ul-nafs); descendants (hifdh-ulnasl); intellect (hifdh-ul-aqal) and wealth (hifdh-ul-maal) (BAZNAS, 2017).

Zakat is one of the practices of philanthropy in Islam. The inherent characteristic of philanthropy is caring for others, feelings of love to fellow human beings, willingness without coercion to help those in need. One of the successes of zakat occurred in the time of Khalifah Umar bin Abdul Aziz, who was a Khalifah in the Umayyah goverment for two and a half years. In this relatively short time, he managed to change the lives of his people. This was described by Ibn Kathir: "Staff Umar exclaims every day, where do people have a loan? Where are people who want to get married? Where are the poor? Where are the orphans? So that I can fulfill the needs of each of them." Umar bin Abdul Aziz became the eighth khalifah in the Umayyah government (Kuliman, 2016).

The distribution of productive zakat can reduce income inequality amongst mustahiq. Productive zakat is the giving of zakat which can make the recipients produce something continuously. Thus, productive zakat funds are developed and used to help business, in 
this way helping them increase their income and fulfill their needs continuously. Moreover, the reduction in the level of income inequality is supported by the role of BAZNAS in Yogyakarta of providing, mentoring, and coaching, so that the capital provided can be managed properly and the role of mustahiq in developing capital and managing business optimized. Therefore, the presence of zakat distribution program is one of the concepts of economic empowerment of the community to reduce the level of income inequality. Another importance that must be emphasized is about how it would perform within the embracement of Sustainable Development Goals. Some topics of SDGs that have been mentioned above from pertaining income inequality, poverty, hunger, and so forth, are several matters that would be addressed with the existence of zakat distribution. The implementation of SDGs and the help from zakat are going to walk to the same direction, which is Maqasid al-Sharia, or the objectives of Islamic rulings.

\section{Conclusion}

Socioeconomic justice and equitable distribution of income and wealth are inseparable from the moral philosophy of Islam. To realize these ideals, Islam imposes the payment of zakat in accordance with the third pillar of Islam (Chapra, 2000). Zakat is one of the philanthropic practices of Islam. The inherent characteristic of philanthropy is caring for others, having feelings of love for fellow human beings, and the willingness to help those in need without coercion. In addition, the zakat distribution can support the achievement of one of the sustainable development goals (SDGs), to reduce inequality.

Instruments that are often used as tools to measure income inequality are the Lorenz curve and the Gini Index (Beik \& Arsyanti, 2016). This is also in line with Todaro (2011), who states that economists usually distinguish between two principal measures of income distribution for both analytical and quantitative purposes: the size distribution of income and production factor income. The usual tools employed to measure income inequality are the Lorenz curve and the Gini index. For this reason, this study use the Lorenz curve and Gini index, together with World Bank crtieria, as the tools to measure the level of income inequality.

The research explains that the distribution of productive zakat by the National BAZNAS of Yogyakarta can reduce income inequality between mustahiq. This is indicated by the narrowed area of the Lorenz curve; in other words, it becomes closer to the equality line after zakat distribution. In addition, the Gini Index fell from 0.37 to 0.30 , while for the income proportion of $40 \%$ of low-income people, there was an increase from $16.83 \%$ to $21.04 \%$. This proves that the distribution of productive zakat by BAZNAS Yogyakarta City can play an active role in increasing the income of mustahiq and reducing income inequality between the rich and the poor.

Based on the results of the study, the distribution of productive zakat can reduce income inequality. Thus, it is expected that BAZNAS can increase the number of 
recipients of productive zakat. For muzaki, muslim community, and the general public are highly expected to pay zakat through BAZNAS of Yogyakarta, so that it can be managed and distributed for those who are entitled to receive. For mustahiq, it is expected to be able to manage the capital of productive zakat funds so that the business can be more developed.

\section{References}

Amar, F. (2017). Implementation of Islamic Philanthropy in Indonesia . AL-URBAN: Journal of Syariah Economics dan Islamic Philanthropy, 1(1), 1-14.

https://doi.org/10.22236/alurban vol1/is1pp1-14

Andiani, K. (2018). Strategy of Collecting and Distributing Zakat through Laku Pandai Agent to Reach Zakat Inclusion in Indonesia. Bogor: Institut Pertanian Bogor.

Ayuniyyah, Qurroh. (2018). Analisis Pengaruh Instrumen Moneter Syariah dan

Konvensional Terhadap Pertumbuhan Sektor Riil di Indonesia. [Skripsi]. Bogor.

Fakultas Ekonomi dan Manajemen, Institut Pertanian Bogor.

BAZNAS, P. K. (2017). A Study of Zakat on SDGS : The Role of Zakat in Sustainable Development Goals to Reach Maqashid Syariah. Jakarta: Pusat Kajian Strategis BAZNAS.

Beik, I. S., \& Arsyanti, L. D. (2016). Syariah Economic Development. Jakarta: RajaGrafindo Persada.

BPS. (2014). Gini Ratio in Yogyakarta City 2014. Yogyakarta: BPS.

BPS. (2017). Gini Ratio in Yogyakarta City 2016. Yogyakarta: BPS.

BPS. (2018). Yogyakarta in Number . Yogyakarta: BPS.

Chapra, U. (2000). Islamic Monetary System. Jakarta: Gema Insani.

Darsono, S. N., \& Donkwa, M. (2016). Factors Analysis of Household Poverty in Rural Area of West Kalimantan, Indonesia. Advances in Management \& Applied Economics, 6(6), 1528. Retrieved from https://ideas.repec.org/a/spt/admaec/v6y2016i6f6 6 2.html

Fathurrahman, A. (2012). Kebijakan Fiskal di Indonesia dalam Perspektif Ekonomi Islam : Studi Kasus Mengentaskan Kemiskinan. Jurnal Ekonomi dan Studi pembangunan, 13(1), 72-82. Retrieved from https://journal.umy.ac.id/index.php/esp/article/view/1265

Hafidhuddin, D. (2004). Zakat in Modern Economy. Depok: Gema Insani.

Ikram, A. D. (2016). The Role of Zakat towards Productivity of Mustahiq (Case Study of Zakat Empowerment in BAZNAS Health Program in Bogor. Bogor: Institut Pertanian Bogor.

Kuliman. (2016). Public Finance Management Policy in the Time of Khalifah Umar bin Abdul Aziz. Journal of Applied Science and Technology, 8(2), 59-66. https://doi.org/10.22216/jit.2014.v8i2.424

Rarasati, I. (2017). Impact Analysis of Agricultural Zakat towards Income Inequality and Poverty Alleviation. Yogyakarta: Universitas Muhammadiyah Yogyakarta.

Rozalinda. (2014). Islamic Economics : The Theory and Application in Economic Activities. Depok: RajaGrafindo Persada.

Sastra, E. (2017). Economic Inequality : Realize Social Justice in Indonesia. Jakarta: PT Mizan Publika.

Todaro, M. P., \& Smith, S. C. (2011). Economic Development. Jakarta: Erlangga. 
Darsono, Raihana, Jati, \& Pachmi

The Impact of Productive Zakat on the Income Inequality ...

Tsani, T. (2010). Analysis of Zakat Distribution Effect to Poverty Rate and Income Inequality (Case Study of Zakat Empowerment by BAZDA in South Lampung). Bogor: Institut Pertanian Bogor.

World Bank. (2015). The Wider Inequality. Retrieved March 27, 2019, from http://pubdocs.worldbank.org/en/986461460705141518/Indonesias-RisingDivide-Bahasa-Indonesia.pdf

World Bank. (2016). Taking on Inequality. Retrieved March 15, 2019, from https://openknowledge.worldbank.org/bitstream/handle/10986/25078/978146480 9583.pdf 